\title{
Treatments to Control Urban River Pollution in Water Source City of South to North Water Diversion Project
}

\author{
Kai Deng ${ }^{1}$, Jianguo Wang ${ }^{3}$, Jianqiang Wang ${ }^{4}$, Wang Chenxi ${ }^{5}$, \\ Changjun Zhang, Xiaoyan Wang ${ }^{1,2 *}$ \\ 'Renmin Hospital, Hubei University of Medicine, Shiyan 442000, China \\ ${ }^{2}$ Department of clinical Oncology, Taihe Hospital, Hubei University of Medicine, Shiyan 442000, China \\ ${ }^{3}$ Center of Health Administration and Development Studies, Hubei University of Medicine, Shiyan 442000, China \\ ${ }^{4}$ Beijing Sports International Economic Conference Service Center, Beijing 100088, China \\ ${ }^{5}$ China Women's University, Beijing 100101, China
}

Received: 7 February 2014 Accepted: 30 April 2014

\begin{abstract}
The city of Shiyan in Hubei Province is the largest city in the source of the South to North Water Diversion Project in China. The water of this project will be sent to Beijing, so water quality is very important. In the city district there is a $100 \mathrm{~km}$ river along a cross-strait with high-rise buildings, dense population, and converged sewage straight flow to the river. In our paper, the design of the "Ming change dark" river closure project can fundamentally solve the city environmental pollution problems, improve the source water quality without any menace from the "rears," and make Shiyan's green economy grow rapidly. On the other hand, this "city agriculture" new thinking will completely change the serious situation of arable land area, which is decreasing year by year in the world. The exploitation of the riverway is an opportunity for Shiyan. It is a green project meaningful to the city's continuing development.
\end{abstract}

Keywords: water pollution, city sewage, South to North Water Diversion Project, Shiyan City, economy

\section{The Situation of Shiyan Riverway}

Shiyan City is the water source city of the South to North Water Diversion Project (Fig. 1) [1]. The urban area of Shiyan is built along the river and all the main roads run parallel to the river [2]. Because of the construction of reservoirs upstream, the rivers always have low flow and are sometimes even dry. Even though there is little water in the riverway, it has almost been polluted. It is estimated that the wide riverway takes up half of its original area, but it merely functions as a sluice just for one month every year. The rest of the year the riverway is a garbage dump.

*e-mail: xywangdk@163.com
Shiyan riverway and reservoir has been repaired, strengthened, and widened since the 1970s. After 40 years the reservoir project is almost finished and the riverway is in good shape [3]. However, from the perspective of the future of the South to North Water Diversion project, of the economy, of the land resource and of Shiyan situation, it is not difficult to notice that many problems have left by the riverway [4]. The riverway has to be disposed of continuously and effectively in order to fulfill its potential.

The bed of the riverway is approximately 5 meters from the streets, its width ranging from 50 meters to 150 meters. Length is 110 kilometers and the average width is 100 meters. The total area of the riverway is $10,000,000 \mathrm{~m}^{2}$. 
For developing mountain city, the riverway should be fully developed [5].

In the $1960 \mathrm{~s}$, the beginning of the establishment of Shiyan city, except plowland and paddy fields, there were clean waters everywhere for people to drink, and wash food and clothes $[6,7]$. In the past, Shiyan was a clean place without any pollution, which could be regarded as a land flowing with milk and honey in the Hanshui Waters [8, 9].

However, the river water in Shiyan now, although claimed as "have been disposed," the citizens feel disgusted even to touch it. In the past there were fish in the river, but now there are not even tadpoles. Due to the worsening of the environment, bird migrations and wild animals have decreased dramatically. In the past, people closed their doors to guard against wild beasts, but now to guard against thieves.

After Shiyan city was built up, the plowland and forests were substituted by high buildings. Moreover, buildings in Shiyan are so crowed that no sunshine can come into the rooms [10].

Required by the construction, the riverway has gone through sand exploitation, which made the riverway neither river nor road. Every flood season, work sheds and construction areas would be damaged by flooding. Therefore, the riverway was turned into today's cement riverbed without any plants. Though flooding is prevented, pollution comes into the way (Fig. 2). The river water stinks and there is rubbish everywhere in the river bed. The disposition and development of the riverway is closely related to the continuous development of Shiyan and to the water quality safety of South-to-North Water Diversion [11]. Thus, to solve this problem is the responsibility, duty, and mission of Shiyan.

\section{The Significance of Disposition and Development of the Riverway}

To dispose and develop the riverway is neither equal to build high buildings along the 10,000,000 $\mathrm{m}^{2}$ riverway nor to fossick in the river bed, but to program and devise reasonably according to different positions. Shiyan shall never follow the same old disastrous road such as sluicing to create manmade lakes or water parks, or to pollute the environment and waste resources [12].

As Shiyan is a mountain city with scarce water and plowland, to dispose of and develop the riverway is meaningful in the following aspects:

The Environment Can Be Beautified, Water Quality of South-to-North Water Diversion Can Be Protected, and City Features

\section{Can Be Revealed}

Shiyan is nicknamed "Automobile City" or "The Detroit of China.' Outlanders may never hear the name of Shiyan, but when "the second automobile manufacturer" or "Mount Wudang" are mentioned, they will understand immediately. This phenomenon may reveal that one city has to maintain its features different from other ones [13]. Since Shiyan is well known for its automobile manufacturer and Mount Wudang, its environment should have a unique style to distinguish itself.

\section{Stop the Endless Exploitation of Natural Resources to Leave Posterity a Place to Survive}

For years, plowland, plants and water resources are decreasing despite calls for their protection. All of a sudden, thousands of acres of plowland became an economic development zone or project base, while no plowland recovery project is seen [14]. It is a common scene even in mountainous Shiyan.

To stop the endless exploitation, and manmade damage, and compensate for the loss of limited resources, Shiyan has to dispose of and reconstruct the riverway completely and effectively.

\section{More Job Opportunities Can Be Provided for Citizens}

A massive labor force has to be pumped into the reconstruction of the riverway. People would get jobs and the

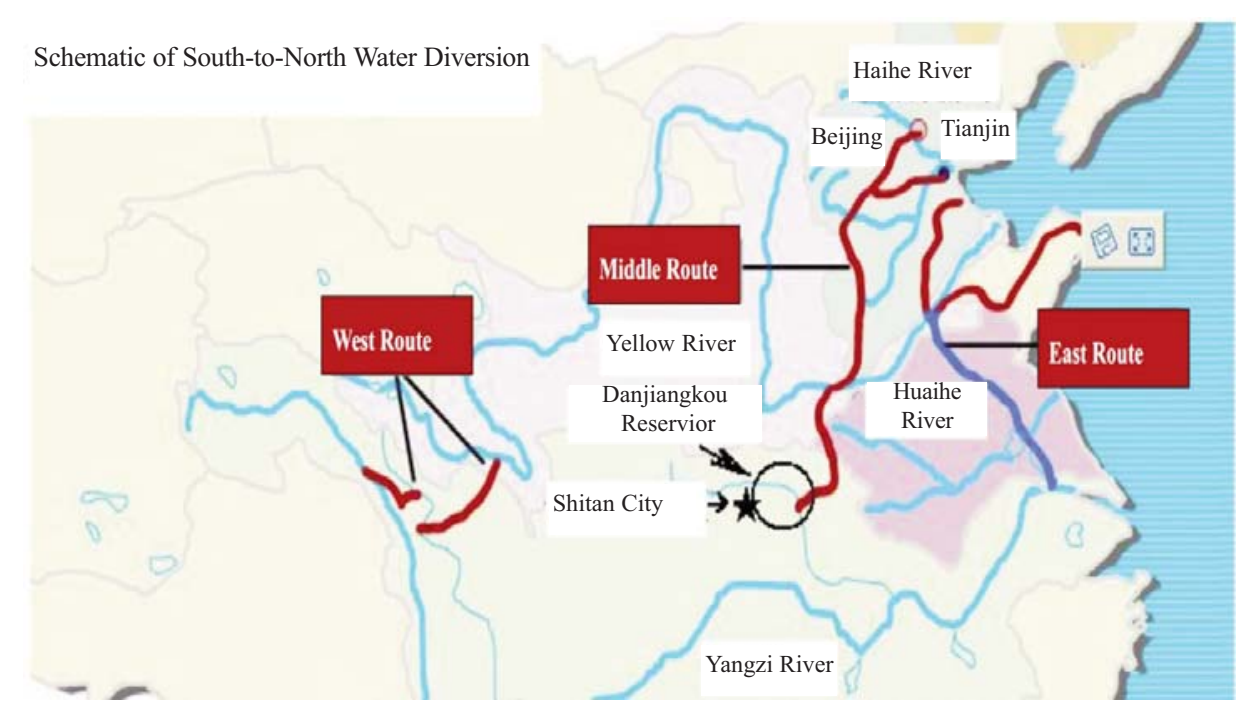

Fig. 1. Location of Danjiangkou reservoir and Shiyan city in the South to North Water Diversion Project. 
architecture market would be revived. Suppose every 100 square meters can provide one position on average, the riverway of $10,000,000 \mathrm{~m}^{2}$ can provide 100,000 positions. As the riverway is closely related with the business zone, residential area, industrial area, service zone, traveling zone, and cultural zone, the integration of the riverway and urban area is inevitable [15].

\section{People's Living Standard Can Be Raised and Spiritual Needs Can Be Satisfied}

As a mountainous city, Shiyan is short of flat land, roads and streets being crowded. Until now, besides two squares for citizens to hold activities, there are only 1-3 m wide pedestrian paths full of cars along the roads.

The need to explore and utilize the riverway is inevitable. In fact, citizens have already gone to the polluted riverbed to join in some cultural activities [16].

Besides shopping malls, restaurants, bars, and automobile manufacturers, lacking touring attractions is a drawback of Shiyan. The riverway in fact can make up for this drawback if it is designed and developed well [17].

\section{The Economy Can Be Promoted and Social Value Can Be Created}

To expand domestic consuming need is the guideline to developing an economy in which a city's development plays a vital role. Because of its location advantage, the riverway in Shiyan may be the life pass of middle route project of South-to-North Water Diversion and a lifeline for the local economy [18].

The economic development of Shiyan mainly depends on automobile manufacture, which made the riverway come into being. Now with the promotion of the South-to-North Water Diversion project, the development of the riverway can also motivate automobile manufacturing [19]. In the future, the South to North Water Diversion project, the vitalization of automobile manufacture, and the development of the riverway will create limitless value for the society.

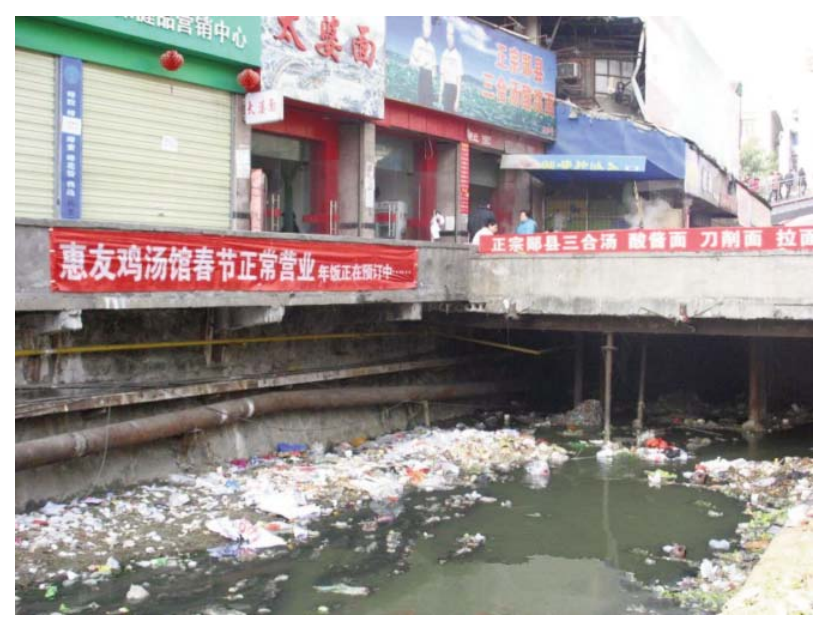

Fig. 2. Sanyan is one of Shiyan City's downtown areas. Along the river, there are intensive shops and restaurants and the river is full of rubbish.

\section{Total Block Out and Brand New Development}

To block out the whole riverway, i.e. to cover the riverway, is the best plan based on the integrated analysis of the overall situation. As a result, the upper part may be utilized in other aspects and the riverway below the cover may discharge flooding as well.

The biggest advantage to covering the riverway is having improved environmental conditions by preventing high temperature radiation of the cement riverbed and emissions of smelly sewage.

The upper part on the cover of the riverway may be utilized in the following ways.

\section{To Develop Plowland}

To develop plowland on the cover of the riverway and to irrigate the plowland with purified water from the riverway below the cover find a way to deal with the sewage, to prevent garbage dumping, to protect the water source for South to North Water Diversion, and to harvest tons of food supply. Moreover, the plowland will make an agricultural touring site; the teenagers in the city can acquire knowledge of agriculture; the climate of the city may be improved directly.

In the past, agriculture only belonged to the countryside and industry only belonged to the city. However, nowadays industry goes into the countryside and so agriculture go can into the city [20].

"The new thinking of city agriculture" also includes advanced project of the roof garden, air farm, beautifying the environment of the city, building area of arable land, and saving the earth's ecological vision [21]

\section{To Plant Plants}

As Shiyan lacks cultural sites, plants may be planted on the cover of riverway and towers, platforms, pavilions and corridors may be built onto it as well to make an integrated cultural site for citizens to entertain, exercise, and tour [22].

\section{To Explore Markets}

The riverway was at one time being used as a vegetable market, which brought convenience for the citizens. But it was removed in 2003 because of SARS. The greengrocers and citizens complained about this decision. Therefore, to explore markets on the cover of the riverway is feasible to ease the difficulty of selling and buying vegetables. The markets may be built like the platforms in a railway station.

\section{Investment}

To block out the riverway is an immense project. Though it may need a large amount of investment, it is profitable because the project is influential and beneficial in many aspects.

According to the policy of "those who invest get the profit,' government may work out detailed rules to encour- 
age units and individuals to invest in the project. Then financial problems may be solved and job opportunities will emerge, as will huge profits.

Suppose the cost of blocking out every square meter is 1,000 RMB, an investment of 10,000,000,000 RMB will be needed. Suppose the profit of every one square meter is 100 RMB, the profit per year is $1,000,000,000$ RMB. Suppose everyday there are 10,000 tourists spending $100 \mathrm{RMB}$ per person, the profit from touring per year is more than $300,000,000$ RMB. So, all the investment can be repaid in as little as 10 years.

\section{Conclusion}

The exploitation of the riverway is an opportunity for Shiyan. It is beneficial for the people, the city, and the country. It is a green project meaningful to the city's continuous development. It will contribute to history.

\section{Acknowledgements}

This research was financially supported by the grants from National Natural Science Foundation of China (81401200), Natural Science Foundation of Hubei Province of China (2013CFB479), Shiyan science and technology research and development projects (14K69).

\section{References}

1. JIANGUO W., XIAOYAN W. Effective Governance Development and Utilization of Headwater City'sRiver Channels in South-to-North Water Diversion - the Sample of Shiyan, Environmental Technology And Knowledge Transfer (5), 915, 2010

2. JING Z., RONG-HUA W., SHU-GUO Y. Sero-epidemiologic Investigation On the Infection of Toxoplasma Gondii among Population in Shiyan Area. Journal of Hubei University of Medicine. 32, (3), June 25, 2013.

3. JINTAO H. The Talk in the Symposium of Population, Resource and Environment (Mar.10 $0^{\text {th }}$, 2004). People's Daily, (4.5), 2, 2004

4. YOUGUANG J. South-to-North Water Diversion: Doublewinning Mode. Entironment and Protection, (4), 6, 2004.

5. YUELING H., JIN Z. Development of City Touring. City Issue, (10), 29, 2008.

6. XIANGXIANG M., JUYING Y., YANYUN L. Cultural and Commercial Touring Development Mode in Historical Cities. City Issue, (10), 54, 2008

7. BALCIOGLU E. B., DEMIRKOL G. T. The Effects of Sulphate, Nitrate, and Humic Substances on Mn(II)
Oxidation with Atmospheric Oxygen in Drinking Water. Pol. J. Environ. Stud. 22, (6), 1601, 2013

8. WEIYU J. Thoughts on Continuous Utilization and Disposition of Freshwater. Science, Technology and Law, (3), 63, 2003.

9. DAMO R., ICKA P. Evaluation of Water Quality Index for Drinking Water. Pol. J. Environ. Stud. 22, (4), 1045, 2013.

10. JIANMING J., DONGXIA J. New Concepts and Measures on Zoology Construction and Protection. Zhejiang Shuren University Academic Paper, (6), 68, 2003.

11. KAIWEN T. Beijing Section of South-to-North Water Diversion Begins Today. Beijing Daily, (12.30), 9, 2003.

12. DOLAR D., KOŠUTIĆ K., IGNJATIĆ ZOKIĆ T., SIPOS L., MARKIĆ M., ŽUPAN M. Combined Methods of Highly Polluted Pharmaceutical Wastewater Treatment-a Case Study of High Recovery. Pol. J. Environ. Stud. 22, (6), 1677, 2013.

13. LI X.J., JI W.L., MA Y.J., ZHOU C.M., LI F., SONG C. Q.Investigation of Water Sources Contaminated by VolatileOrganic Compounds in Jiangsu Province. Huan Jing Yu JianKang (Environ Health). 24, 877, 2007 [In Chinese].

14. ELLIS P.A., RIVETT M.O. Assessing the impact of VOCcontaminated groundwater on surface water at the city scale. J. Contam. Hydrol. 91, 107, 2007.

15. WANG J., DA L., SONG K., LI B.L. Temporal variations ofsurface water quality in urban, suburban and rural areas dur-ing rapid urbanization in Shanghai, China. Environ Pollut. 152, 387, 2008.

16. RAKAD A. TA'ANY, TAREK G. AMMARI, ANWAR JIRIES. Revegetation in Arid Zones: Environmental Impact of Treated Wastewater Irrigation in Al-Karak Province, Jordan. Pol. J. Environ. Stud. 22, (2), 569, 2013.

17. HAN F., CHEN J., JIANG Z., CHEN L., JI W. Volatile and Semi-Volatile Organic Compounds in the Lower Yangtze River and Surface Waters of Three Chinese Provinces. Pol. J. Environ. Stud. 22, (3), 683, 2013.

18. TANG Z.W., YANG Z.F., SHEN Z.Y., NIU J.F. Pentachlorophenol residues in suspended particulate matterand sediments from the Yangtze River catchment of Wuhan, China. B. Environ. Contam. Tox. 158-162, 2007.

19. CHEN L., ZHOU Y., WU Y., ZHANG H. Status of traceorganic pollution in the network water came from HuangpuRiver. Wei Sheng Yan Jiu (Hygiene Research). 37, 137, 2008 [In Chinese].

20. CHUN-RONG WANG, REN X., WEN-XIU LI, ZHI-FEI HOU, KE C., GENG Q. Adsorption of Zinc and Copper Heavy Metal Ions from Smelting Wastewater Using Modified Lava Particles. Pol. J. Environ. Stud. 22, (6), 1863, 2013.

21. RICHTER P., PECHAROVÁ E. Effects of Mining Activities on River Water Quality. Pol. J. Environ. Stud. 22, (4), 1269, 2013.

22. PINDI P. K., RAGHUVEER YADAV P., KODAPARTHI A. Bacteriological and Physico-Chemical Quality of Main Drinking Water Sources. Pol. J. Environ. Stud. 22, (3), 825, 2013. 